Live Long and Prosper 
This page intentionally left blank 


\section{Live Long and Prosper}

\section{How Black Megachurches Address HIV/AIDS and Poverty in the Age of Prosperity Theology}

\section{Sandra L. Barnes}


Copyright (C) 2013 Fordham University Press

All rights reserved. No part of this publication may be reproduced, stored in a retrieval system, or transmitted in any form or by any means-electronic, mechanical, photocopy, recording, or any other-except for brief quotations in printed reviews, without the prior permission of the publisher.

Fordham University Press has no responsibility for the persistence or accuracy of URLs for external or third-party Internet websites referred to in this publication and does not guarantee that any content on such websites is, or will remain, accurate or appropriate.

Fordham University Press also publishes its books in a variety of electronic formats. Some content that appears in print may not be available in electronic books.

Library of Congress Cataloging-in-Publication Data is available from the publisher.

Barnes, Sandra L.

Live long and prosper : how Black megachurches address HIV/AIDS and poverty in the age of prosperity theology / Sandra L. Barnes.—1st ed.

p. cm.

Includes bibliographical references (p. ） and index.

ISBN 978-o-8232-4956-5 (cloth : alk. paper)-ISBN 978-0-8232-4957-2 (pbk. : alk. paper)

1. African Americans-Religion. 2. Big churches. 3. African American

churches. 4. Black theology. 5. Poverty-Religious aspects-Christianity.

6. Church work with the poor. 7. AIDS (Disease)-Religious aspects-Christianity.

8. Church work with the sick. 9. Faith movement (Hagin) I. Title.

BR563.N4B3785 2013

277.3 '08308996073-dc23

2012022301

Printed in the United States of America

$\begin{array}{llllllll}15 & 14 & 13 & 5 & 4 & 3 & 2 & 1\end{array}$

First edition 
To my mother, Clara Brown, as well as my sisters, Debra, Vonda, Benita, and Karla, who each continually exhibit what is best in humanity—in both word and deed. 
This page intentionally left blank 